\title{
Rural avenues as a refuge for feral honey bee population
}

\author{
Andrzej Oleksa • Robert Gawroński • \\ Adam Tofilski
}

Received: 17 March 2012/ Accepted: 17 August 2012/Published online: 30 August 2012

(C) The Author(s) 2012. This article is published with open access at Springerlink.com

\begin{abstract}
Several honey bee (Apis mellifera) subspecies are in danger of local extinction because their feral population have almost completely disappeared. An important threat to the feral populations of bees is loss of habitat and loss of woodlands. In many places the only habitat suitable for honey bee nesting are rows of trees along roadsides. We studied a feral population of honey bees inhabiting avenues in northern Poland. We inspected $142 \mathrm{~km}$ of avenues and found 45 feral colonies. The estimated density of feral population inhabiting the avenues was 0.10 nest $\mathrm{km}^{-2}$. Honey bees preferred to build their nests in trees with a thick trunk and a somewhat weak state of health. There was no strong preference of bees to any species of trees. We stress the importance of protection of existing avenues and creating new ones. This can provide suitable habitat not only for honey bees but also for other endangered species.
\end{abstract}

Keywords Apis mellifera - Honey bee $\cdot$ Hollow tree . Feral population

\section{Introduction}

The honey bee (Apis mellifera) is native to Africa, Middle East and Europe, except its most northern part (Ruttner

\footnotetext{
A. Oleksa $(\square)$

Department of Genetics, Kazimierz Wielki University, Chodkiewicza 30, 85-064 Bydgoszcz, Poland

e-mail: olek@ukw.edu.pl

R. Gawroński

Kasprowicza 8, 14-300 Morąg, Poland

A. Tofilski

Department of Pomology and Apiculture, Agricultural University, 29 Listopada 54, 31-425 Kraków, Poland
}

1988). In this area, more than twenty subspecies or geographical races have been described (Ruttner 1988). Some of the subspecies are at local risk of extinction. The major threats to feral honey bees include: intensive land use, spread of new pathogens and introductions of non-native subspecies by beekeepers (De la Rúa et al. 2009). Feral (unmanaged) population of honey bees have almost completely disappeared in Europe (Jaffé et al. 2010). In many places, managed populations kept by beekeepers in hives do not consist of native subspecies. For example in Germany the native A. m. mellifera was to a large degree hybridised with A. m. carnica (Moritz 1991; Maul and Hähnle 1994).

In some parts of the world there are viable feral populations of honey bees. Relatively large natural populations are still present in Africa (Dietemann et al. 2009). The feral populations are also present in places where the honey bee was introduced, for example in North America (Seeley 1978), South America (Schneider et al. 2004) and Australia (Oldroyd et al. 1997). In Europe feral colonies of honeybees are relatively rare and were found in British Isles and Italy (Jaffé et al. 2010; Thompson et al. 2010). Some of the feral populations in Europe can be small and consist mainly of swarms which have escaped from managed apiaries.

An important threat to the feral populations of bees is loss of habitat (Brown and Paxton 2009; De la Rúa et al. 2009). In natural conditions tree cavities are usually used by the bees for nesting (Seeley and Morse 1976). Suitable cavities may be found only in large and old trees which are generally rare in Europe, where most woodland areas were replaced with agricultural landscape or have been intensively managed. Therefore it was suggested that the main strategy of bees conservation should be minimising habitat loss and making agricultural habitats bee-friendly (Brown and Paxton 2009).

The elements of agricultural landscape which are particularly bee-friendly are avenues, i.e. routes lined with 
trees. Many of the avenues were planted in previous centuries (Couch 1992) and now consist of old trees with cavities suitable for honey bee nesting. Moreover, some of the tree species, for example lime trees (Tilia sp.) can provide bees with nectar and pollen. The avenues are still present in many parts of Europe including: France, Germany (Lehmann and Rohde 2006), Switzerland (Tartaro and Kunz 2008), Denmark, Sweden, Poland (Pradines 2009) and Great Britain (Crane 2001). The avenues are important not only to honey bees but also other insects which deserve protection (Oleksa et al. 2006; Oleksa et al. 2007).

The aim of this study was to verify if the avenues in agricultural landscape can support viable feral population of honey bees. We estimated the density of the population and described trees in which bees build their nests.

\section{Methods}

Area under study

The study was carried out in the northern Poland $\left(18^{\circ} 36^{\prime}-\right.$ $21^{\circ} 1^{\prime} \mathrm{E}, 53^{\circ} 14^{\prime}-54^{\circ} 24^{\prime} \mathrm{N}$ ) between June and the beginning of September in two consecutive years, 2010 and 2011. The climate of the studied region is one of the coldest in lowland Poland. It is influenced by the Baltic Sea, marked with a continental impact. The average annual temperature is about $7{ }^{\circ} \mathrm{C}$. The vegetation period lasts 190-200 days per year. Average annual precipitation ranges from 600 to $700 \mathrm{~mm}$ (Woś 1999). The dominant form of land use is agriculture, especially intensive in the fertile soils in the delta of the Vistula River as well on clay moraines of the
Vistulian (Weichselian) glaciation (Kondracki 2002). About $68 \%$ of the studied area consists of lands that are used for agricultural purposes (mainly arable land, but also orchards and meadows), while forest covers $26.8 \%$ of the total area. It was shown that native A. m. mellifera still occurs in the region adjacent to the study area (Meixner et al. 2007; Oleksa et al. 2011).

Field methods

To determine the occupation of trees by feral colonies of honey bee, an extensive survey of trees was conducted. Detailed inventories of avenues (trees planted along roads) were conducted at sites designated in advance (Fig. 1). These sites were selected to ensure uniform coverage of the studied area by generating evenly distributed points using the tool "Regular points" of the plug-in fTools for the Quantum GIS software (Quantum GIS Development Team 2010). Points were generated so that the distance between them was about $10 \mathrm{~km}$, assuming a random deviation of each point from the uniform grid. Points were then displayed on the background of current aerial photographs (Google Earth and geoportal.gov.pl) and manually shifted to the nearest avenues (i.e. linear stands of trees along roads). If the inspection in the field proved that the location had been wrongly identified (usually, linear tree stand turned out to be cluster of trees along a watercourse instead of a road), then the closest avenue was chosen instead.

At each site, a sample of approximately 70 trees was examined. Tree position was determined using a GPS receiver (PathFinder ProXT, Trimble). The trees were described in terms of several variables, i.e. tree species identity, trunk diameter at $1.3 \mathrm{~m}$ ("diameter at breast
Fig. 1 a Location of avenues with feral nests (filled circles) and avenues without feral nests (empty circles); b The study area was divided into 170 polygons and 17 of them (filled) were used for estimating density of the avenues; $\mathbf{c}$ location of the study area in Europe
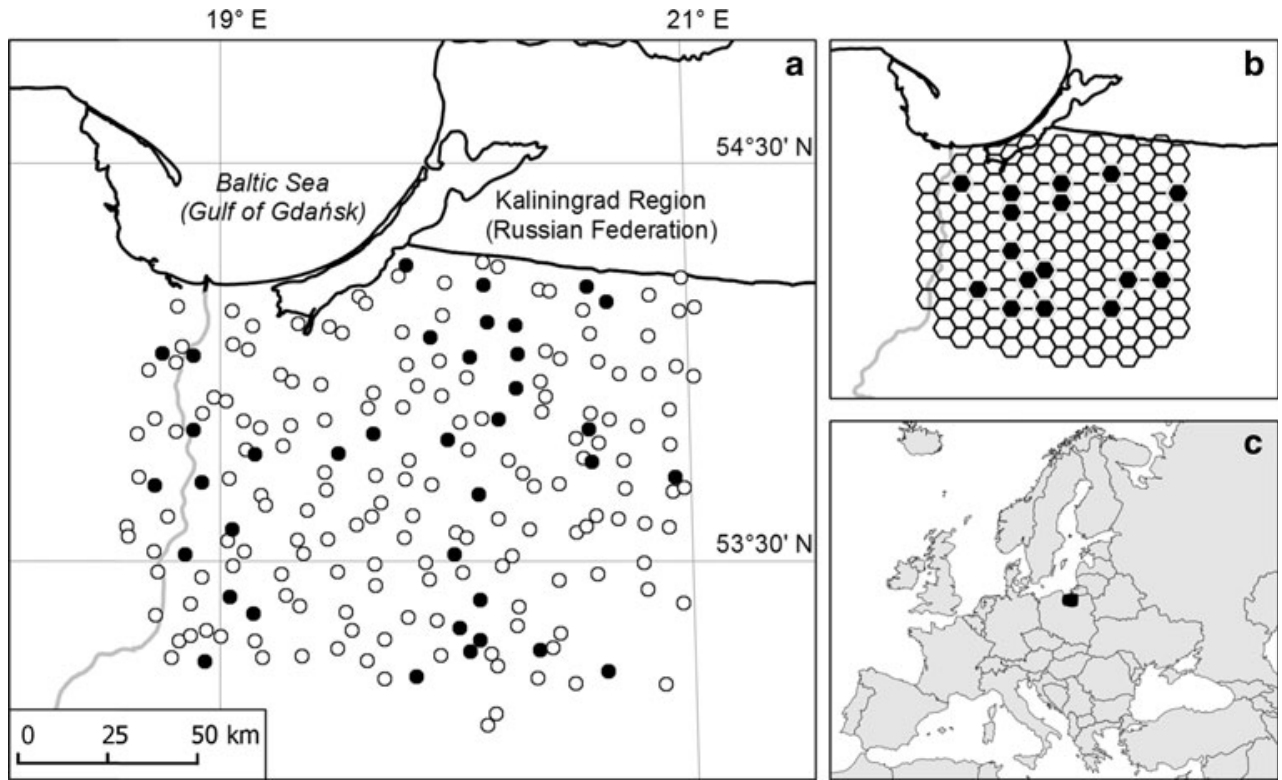
height", DBH), health state and the presence of hollows and bee colonies. Lime trees Tilia sp. were determined to the genus level because we encountered hybrids, however in most cases (ca. $90 \%$ ) Tilia sp. refers to small-leaved lime T. cordata, native to northern Poland. The presence of hollows was assessed by visual inspection from the ground level, in doubtful cases supplemented by tapping the trunk and inspection with a ladder. We used the 5 point scale of Pacyniak (1992) to assess tree health 1 -trunk and crown healthy; 2-hollows possible, up to $25 \%$ of crown damaged (loss); 3-25-50\% damaged (loss); 4-50-75\% damaged (loss); 5-above $75 \%$ damaged (loss) or a dead tree. Trees with health status 1 by definition are not hollow; trees with poor health could contain cavities.

Detection probability of insect could be affected by air temperature and overall weather condition. In order to eliminate the effect of temperature, observations were conducted when the temperature exceeded $15{ }^{\circ} \mathrm{C}$. Trees were carefully viewed from all sides in search of bees entering/exiting hollows or of flying in their vicinity. Buzzing sound generated by the colony provided another important clue in detecting of bees. In case of Tilia sp trees, special care was taken during the time of their flowering, in order to make sure that detected bees were confirmed to be nesting in hollows of the particular tree examined.

\section{Statistical methods}

The occurrence of honey bee colonies was examined at two levels. First, we used data concerning all examined trees to qualify preferences of bees for specific characteristics of trees. Next, we computed summary characteristics of the entire field sites (avenues) to check whether there are some characteristics allowing prediction of bee occurrence at this level.

\section{Tree level}

We used generalized linear/non-linear models or GLZs with a binomial distribution of the response variable and Logit link function to describe the presence/absence of honey bee colonies in trees in relation to tree species, health state and trunk diameter. Such specified GLZ method is equivalent to Logistic regression, which is commonly used to estimate occurrence probabilities in relation to predictors, however, it allows for including categorical predictor variables. As input, only data concerning hollow trees were included as only such trees represented potential nesting site for bees. In order to develop an optimal set of explanatory variables responsible for presence/absence of bee colonies, a comparison of all possible GLZs was performed to find the most parsimonious model. The selection of final variables in the GLZ model was based on Akaike's information criterion (AIC). AIC provides a measure of model fit and penalizes candidate models for including variables that do not add explanatory power to the result. We used AIC weights $(\omega \mathrm{i})$ to generate weighted model-averaged parameter estimates. We used ANOVA to compare averages between groups. Computations were done with Statistica v10.0 software (Statsoft 2011).

Preferences of feral bees with respect to tree species, circumference and health state were further compared with a random sample model. Occurrences of bee colonies were randomly drawn from the overall pool of trees and the resulting frequencies per variables (species identity, circumference and health state) were compared with the observed ones. Expected frequencies and standard deviations were generated from 5,000 random samples each using the program Sample (Ulrich 2003, Ulrich and Ollik 2005). The frequency distribution of these random samples was in all cases approximately normally distributed. Hence we used the common Z-transformation $[Z=(x-\mu) / \sigma]$ to infer the probability levels for the observed values from the standard normal distribution. $Z$-scores above 2 or below -2 indicate significant $(p<0.05)$ deviations of the observed value $x$ from expectation $\mu$.

\section{Site level}

Again, a GLZ model with a binomial distribution of the response variable and Logit link function was derived to describe the presence/absence of honey bee colonies in relation to characteristics of avenues. Each avenue was characterized in terms of proportion of trees with hollows, average health state and average DBH. A comparison of all possible GLZs was performed to find the best model based on Akaike information criterion.

The regression approach outlined above is based on the assumption that the values of observations in each sample are independent one from another. The existence of spatial autocorrelation in dependent variables could bias this assumption, therefore it was checked by computing Moran's coefficient (I) with SAM ver. 4.0 software (Rangel et al. 2010).

\section{Estimation of population density}

To estimate the overall density of the population throughout the region, we computed average density of bee colonies in the inventoried avenues. The obtained data were extrapolated in order to obtain value corresponding to the entire area. To do that, we estimated density of the avenues. The study area was divided into hexagonal $100 \mathrm{~km}^{2}$ polygons (QMarxan tool in Quantum GIS software, Quantum GIS Development Team 2010) and $10 \%$ of them 
( $\mathrm{N}=17$ ) were randomly selected for detailed avenue inventory (Fig. 1b). Tree-lined avenues within these polygons were mapped based on aerial photographs and verified during field examination.

\section{Results}

Occurrence of bees in trees

In total, 15,115 trees on 201 sites were examined. In this sample, 3,571 trees were recognized as possessing hollows (23.6\% of all trees), and 45 trees were occupied by colonies of bees (Fig. 2); bees occurred in $0.3 \%$ of all trees and in $1.3 \%$ of hollow trees.

DBH (average \pm SD) of trees without hollows, hollow trees without honey bee nest and hollow trees with honey bee nest was: $59.7 \pm 19.7 \mathrm{~cm}, \quad 71.5 \pm 19.9 \mathrm{~cm}$ and $76.5 \pm 17.0 \mathrm{~cm}$, respectively (Fig. 2). One-way ANOVA showed that mean DBH differed significantly between the three groups $\left(\mathrm{F}_{2,15112}=497.5, p<0.0001\right)$.

Comparison of observed numbers of occupied trees and values expected from the random sample model for assumed diameter classes showed that bees avoided trees thinner than $50 \mathrm{~cm}(\mathrm{Z}=-2.08, p=0.04$; Table 1$)$. Conversely, there was a slight tendency towards occupancy of trees with diameter $100-125 \mathrm{~cm}$, however this result was not statistically significant $(\mathrm{Z}=1.71, p=0.09)$.

The largest number of colonies was recorded on lime trees Tilia sp. (28 records, i.e. $62.2 \%$ off all observations), nine colonies were found in Norway maple (Acer platanoides), three in European ash (Fraxinus excelsior), two in pedunculate oak (Quercus robur) and one colony in each of several other species: sycamore maple (Acer pseudoplatanus), horse-chestnut (Aesculus hippocastanum) and black alder (Alnus glutinosa). When the frequencies of bee colonies were compared with the expectations of the null

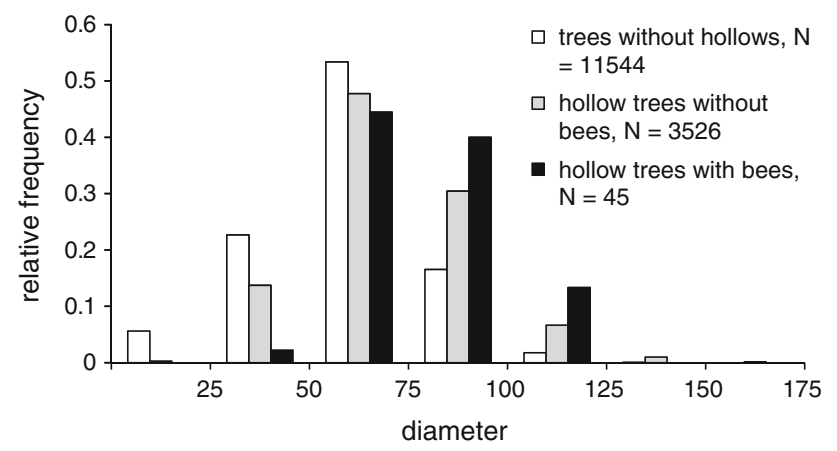

Fig. 2 Relative frequency of trees with various diameters. The trees were divided into three groups: trees without hollows (white bars), hollow trees without honey bee nest (gray bars) and hollow tree with honey bee nest (black bars) model (random colonisation of hollow trees, depending on their availability), it turned out that bees showed preference to Alnus glutinosa and avoidance of Carpinus betulus (Table 2). The lack of records from hornbeams could be probably attributed to small trunk diameter of these trees (average diameter of hollow C. betulus was $52.8 \mathrm{~cm}$, while other species of trees occupied by bees had average diameter 73.4; the difference was highly significant, $p<0.001$ ).

No significant departures from the expectations of the random sample model were observed for health classes (Table 3). Most bee colonies were encountered in trees of health class 2 , however it should be noted that such trees are the most abundant in avenues due to selective removal of trees with the worse health by road managers.

Based on the data containing 45 occupied hollow trees and 3,526 hollow trees without bees, we estimated parameters of GLZ model explaining presence/absence of bee colonies in hollow trees (Tables 4, 5). An increasing probability of bee occurrence was associated with tree diameter, i.e. thicker trees were colonised at a higher chance, however this variable was barely significant $(p=0.058)$. Incorporation of tree species in the GLZ model did not improve its explanatory power. Table 6 shows AIC-weighted model-averaged parameter estimates.

\section{Occurrence of bees in avenues}

Honey bee colonies were recorded in 37 of 201 studied fragments of avenues (18.4\% of all sites, Fig. 1). Occupation of sites by bees as well as all explanatory variables did not show any signs of spatial aggregation (Moran's $I$ statistics showed no significant difference from 0 ). Therefore, all data points were treated as independent and estimation of the single global model was valid.

The best GLZ model included only the proportion of hollow trees in avenue fragment as the most informative predicator of bee presence (Table 5). The variables eliminated from the model were average tree diameter and average tree health. Although tree size and health were positively associated with bee occurrence, their inclusion did not result in improved performance of the model.

Estimation of population density

Examined avenue fragments had total length of $142.0 \mathrm{~km}$. In these stretches we found 45 colonies of honeybees. It gave the density of 0.32 colonies per kilometre of avenue. The density of avenues in the 17 polygons inventoried in details ranged between 0.26 and $0.38 \mathrm{~km} \mathrm{~km}^{-2}$ with an average of $0.31 \pm 0.04 \mathrm{~km} \mathrm{~km}^{-2}$ (mean $\pm \mathrm{SD}$ ). The density of feral colonies in the study area was estimated to be 0.10 nests $\mathrm{km}^{-2}$. 
Table 1 Differences between observed and expected occupancies of hollow tree diameter classes

Expected occupancies were obtained by a random sampling of 45 trees (the actual number of trees in which bee colonies were found in) out of the total of 3,571 hollow trees. Significant values are shown in bold

Table 2 Differences between observed and expected occupancies of hollow trees belonging to different species

Significant values are shown in bold

\begin{tabular}{lccllll}
\hline $\begin{array}{l}\text { Diameter } \\
\text { (upper limit, cm) }\end{array}$ & $\begin{array}{l}\text { Number } \\
\text { of trees } \\
\text { with hollows }\end{array}$ & $\begin{array}{l}\text { Number } \\
\text { of trees } \\
\text { with bees }\end{array}$ & $\begin{array}{l}\text { Expected } \\
\text { number of } \\
\text { occupied trees }\end{array}$ & SD & $Z$ & $p$ \\
\hline 25 & 10 & 0 & 0.1 & 0.35 & -0.36 & 0.72 \\
50 & 485 & 1 & 6.1 & 2.46 & -2.08 & $\mathbf{0 . 0 4}$ \\
75 & 1,703 & 20 & 21.5 & 4.60 & -0.32 & 0.75 \\
100 & 1,091 & 18 & 13.7 & 3.68 & 1.15 & 0.25 \\
125 & 241 & 6 & 3.0 & 1.73 & 1.71 & 0.09 \\
150 & 36 & 0 & 0.5 & 0.67 & -0.68 & 0.50 \\
175 & 5 & 0 & 0.1 & 0.25 & -0.25 & 0.80 \\
Total & 3,571 & 45 & & & & \\
\hline
\end{tabular}

\begin{tabular}{|c|c|c|c|c|c|c|}
\hline Tree species & $\begin{array}{l}\text { Number of } \\
\text { trees with } \\
\text { hollows }\end{array}$ & $\begin{array}{l}\text { Number } \\
\text { of trees } \\
\text { with bees }\end{array}$ & $\begin{array}{l}\text { Expected } \\
\text { number of } \\
\text { occupied trees }\end{array}$ & SD & $Z$ & $p$ \\
\hline Acer platanoides & 638 & 9 & 8 & 2.82 & -0.01 & 0.99 \\
\hline Acer pseudoplatanus & 51 & 1 & 1 & 0.80 & 0.45 & 0.65 \\
\hline Acer saccharinum & 2 & 0 & 0 & 0.16 & -0.16 & 0.87 \\
\hline Aesculus hippocastanum & 62 & 1 & 1 & 0.88 & 0.25 & 0.80 \\
\hline Alnus glutinosa & 8 & 1 & 1 & 0.32 & 2.85 & 0.004 \\
\hline Betula pendula & 69 & 0 & 0 & 0.93 & -0.94 & 0.35 \\
\hline Carpinus betulus & 315 & 0 & 0 & 1.98 & -2.01 & 0.04 \\
\hline Fagus sylvatica & 21 & 0 & 0 & 0.51 & -0.52 & 0.60 \\
\hline Fraxinus excelsior & 131 & 3 & 3 & 1.28 & 1.06 & 0.29 \\
\hline Fraxinus pensylvanicus & 4 & 0 & 0 & 0.22 & -0.23 & 0.82 \\
\hline Malus domestica & 25 & 0 & 0 & 0.56 & -0.56 & 0.57 \\
\hline Populus balsamifera & 3 & 0 & 0 & 0.19 & -0.20 & 0.84 \\
\hline Populus tremula & 1 & 0 & 0 & 0.11 & -0.11 & 0.91 \\
\hline Populus $\times$ canadensis & 3 & 0 & 0 & 0.19 & -0.20 & 0.84 \\
\hline Pyrus communis & 1 & 0 & 0 & 0.11 & -0.11 & 0.91 \\
\hline Quercus petrea & 1 & 0 & 0 & 0.11 & -0.11 & 0.91 \\
\hline Quercus robur & 108 & 2 & 2 & 1.16 & 0.55 & 0.58 \\
\hline Quercus rubra & 1 & 0 & 0 & 0.11 & -0.11 & 0.91 \\
\hline Salix alba & 5 & 0 & 0 & 0.25 & -0.25 & 0.80 \\
\hline Salix caprea & 1 & 0 & 0 & 0.11 & -0.11 & 0.91 \\
\hline Sorbus intermedia & 12 & 0 & 0 & 0.39 & -0.39 & 0.70 \\
\hline Tilia $\mathrm{sp}$. & 2,108 & 28 & 27 & 5.12 & 0.09 & 0.93 \\
\hline Ulmus laevis & 1 & 0 & 0 & 0.11 & -0.11 & 0.91 \\
\hline Total & 3,571 & 45 & & & & \\
\hline
\end{tabular}

\section{Discussion}

The results presented here show that rural avenues are inhabited by feral colonies of honey bees. The density of the feral population $\left(0.10\right.$ nests $\left.\mathrm{km}^{-2}\right)$ seems relatively low but comparable to some earlier reports: 0.2 (arid island, Wenner 1989), 0.4 (temperate forest, Galton 1971), 0.5 (temperate forest, Visscher and Seeley 1982), 0.4-1.1 (urban environment, Baum et al. 2008). In most studies the density of feral populations was much larger: 2.3 (urban environment, Morse et al. 1990), 2.4-3.2 (national park, Moritz et al. 2007), 4.2 (savannah, McNally and Schneider 1996), 6.2-9 (agricultural environment, Ratnieks et al. 1991), 7.8 (savannah, Schneider and Blyther 1988), 12.5 (urban environment, Baum et al. 2005), 12.4-17.6 (savannah, Moritz et al. 2007), 40-148 (riparian woodland, Oldroyd et al. 1994; Oldroyd et al. 1997). The density of the feral population of honey bee inhabiting avenues is 
Table 3 Differences between observed and expected occupancies of hollow tree health classes

\begin{tabular}{|c|c|c|c|c|c|c|}
\hline $\begin{array}{l}\text { Health state } \\
\text { class }\end{array}$ & $\begin{array}{l}\text { Number of trees with } \\
\text { hollows }\end{array}$ & $\begin{array}{l}\text { Number of trees } \\
\text { with bees }\end{array}$ & $\begin{array}{l}\text { Expected number of } \\
\text { occupied trees }\end{array}$ & SD & $Z$ & $p$ \\
\hline 2 & 3,150 & 37 & 39.7 & 6.26 & -0.43 & 0.67 \\
\hline 3 & 358 & 7 & 4.5 & 2.11 & 1.18 & 0.24 \\
\hline 4 & 46 & 0 & 0.6 & 0.76 & -0.77 & 0.44 \\
\hline 5 & 17 & 1 & 0.2 & 0.46 & 1.71 & 0.09 \\
\hline Total & 3,571 & 45 & & & & \\
\hline
\end{tabular}

Table 4 Model selection results for the effect of trunk diameter (DBH), tree health and tree species on the presence of honey bee nests in hollow trees

\begin{tabular}{lllllc}
\hline Rank & Model & K & AIC & $\Delta$ AIC & $\omega \mathrm{i}$ \\
\hline 1 & DBH & 2 & 483.49 & 0 & 0.461 \\
2 & DBH + health & 3 & 483.89 & 0.40 & 0.377 \\
3 & Health & 2 & 485.59 & 2.10 & 0.161 \\
4 & Tree species & 2 & 510.81 & 27.32 & $<0.0001$ \\
5 & DBH + tree species & 3 & 511.05 & 27.56 & $<0.0001$ \\
6 & Health + tree species & 3 & 511.26 & 27.77 & $<0.0001$ \\
7 & DBH + health + tree & 4 & 511.46 & 27.97 & $<0.0001$ \\
& species & & & & \\
\hline
\end{tabular}

The model selection statistics are: number of parameters (K), Akaike's information criterion (AIC), difference between model and minimum AIC values $(\triangle \mathrm{AIC})$, and AIC weights $(\omega \mathrm{i})$

much lower than the density of managed populations, which is estimated to be 4.4 nests $\mathrm{km}^{-2}$ for the study area (Semkiw and Skubida, 2010).

The population density reported in this study can be an underestimation because some colonies could have been overlooked, particularly when their nest entrance was located high above the ground. In addition, the population present in the avenues is probably only a part of larger feral population present in woodlands, which cover $27 \%$ of the study area. It is not clear what proportion of the feral colonies started as swarms which escaped from managed colonies. At least some of the cavities were occupied by bees during the last 3 years (unpublished data). Part of the managed population is not subjected to artificial selection.
Table 6 AIC-weighted model-averaged parameter estimates generated from the top three models of presence of honey bee nests in hollow trees (Table 4, $\Sigma \omega \mathrm{i}=1.000$ ) and avenues (Table 5, $\Sigma$ $\omega \mathrm{i}=0.839$ )

\begin{tabular}{llrl}
\hline Level of analysis & Variable & Coeff & SE \\
\hline Tree level & DBH & 0.877 & 0.465 \\
& Health & 0.114 & 0.082 \\
& (Intercept) & -8.805 & 2.401 \\
Site level (avenues) & Prop. of hollow trees & 2.200 & 0.652 \\
& Average DBH & 0.006 & 0.006 \\
& Average health & -0.011 & 0.065 \\
& (Intercept) & -2.577 & 1.004 \\
\hline
\end{tabular}

Every year on average $51 \%$ of managed colonies are requeened in Poland and most of the queens comes from swarming, supersedure and own breeding, only $28 \%$ of them are purchased from queen breeders (Bieńkowska, 2012). Even the purchased queens usually are not inseminated and mate with local population of drones. As a result $79 \%$ of managed colonies in the study area do not differ from A. m. mellifera (unpublished data). In this situation the feral population inhabiting rural avenues should be considered as an important reservoir of genetic variation.

In our study, the occupancy of any particular tree species depended mainly on its availability. However, we observed two exceptions to this pattern. First, the occupancy of alders was higher than expected, and secondly, hornbeams were avoided. The first observation may be biased by the small sample of alders, but the latter one probably reflects the fact
Table 5 Model selection results for the effect of avenue characteristics on the presence of honey bee nests

Abbreviation as in Table 4

\begin{tabular}{llllll}
\hline Rank & Model & K & AIC & $\Delta$ AIC & $\omega$ i \\
\hline 1 & Prop. of hollow trees & 2 & 186.94 & 0 & 0.41 \\
2 & Average DBH + prop. of hollow trees & 3 & 187.77 & 0.83 & 0.27 \\
3 & Average health + prop. of hollow trees & 3 & 188.86 & 1.92 & 0.16 \\
4 & Average DBH + average & 4 & 189.50 & 2.56 & 0.11 \\
& $\quad$ health + prop. of hollow trees & & & & \\
5 & Average DBH & 2 & 192.11 & 5.17 & 0.03 \\
6 & Average DBH + average health & 3 & 194.07 & 7.13 & 0.01 \\
7 & Average health & 2 & 195.88 & 8.94 & 0.005 \\
\hline
\end{tabular}


that hornbeam are usually not appropriate for bees due to relatively small trunk diameter. Contrary to our expectation bees did not prefer lime trees for nesting. The greater occurrence of bee colonies in this tree species could be fully explained by its greater availability.

Although native subspecies of honey bees can be protected in managed apiaries and such protection can be essential in some places (De la Rua et al. 1998), a feral population should be considered as an important part of the protection program. Feral colonies usually consist of native subspecies which are under natural selection pressures to survive in local environment. Moreover, the feral colonies have higher genetic diversity than managed colonies (Moritz et al. 2007; Lowe et al. 2011). On the other hand, honey bee breeders often selectively breed subspecies preferred by beekeepers (Magnus et al. 2011). In most places there is no regulations prohibiting import of non-native subspecies and even if there are such regulations it is difficult to enforce them.

In places where the natural environment has been replaced with agriculture, avenues of trees can be a refuge for the feral population of honey bee. Even if the avenues only support a low density population, there should be no problems with inbreeding because of the large mating range of queens and drones (Jensen et al. 2005). Unfortunately the avenues are relatively rare. In Europe they are present only in some places and they are gradually disappearing (Pradines 2009). The data presented here show that hollow trees, thicker than $50 \mathrm{~cm}$ in diameter, should be particularly preserved as potential nesting sites for honey bees. The avenues not only should be protected and restored but new (replacement) avenues should be planted. Despite not confirming that honey bees prefer to build their nests in lime trees or maple trees, the two species can be particularly suitable for planting in avenues because they provide not only nesting sites but also nectar and pollen for bees and other insects. Although lime trees produce more nectar (Corbet et al. 1979; Waś et al. 2011) than maple trees (Haragsim 1977), the later species grows faster (Rowntree and Nowak 1991; Larsen and Kristoffersen 2002) and can reach trunk diameter suitable for honey bee nesting earlier. The two species also flower at different time of year and avenues consisting of both species can provide bees with food both in spring and in summer.

The data presented here allow us to conclude that avenues of trees should be protected as a potential nesting site for feral colonies of honey bees. We recommend planting new mixed species avenues consisting of both lime trees and maple trees.

Acknowledgments The research was conducted within the project "Roads for Nature", co-ordinated by Foundation for Sustainable Development and supported by EU Infrastructure and Environment Operational Programme and National Fund for Environmental Protection and Water Management. It was also partially supported by a grant "Wild living bees-origin and importance for conservation of genetic resources of the native subspecies Apis mellifera mellifera" from the Polish Ministry of Science and Higher Education (grant No. N N311 509639). We thank the anonymous reviewer for constructive recommendations for improving this manuscript.

Open Access This article is distributed under the terms of the Creative Commons Attribution License which permits any use, distribution, and reproduction in any medium, provided the original author(s) and the source are credited.

\section{References}

Baum KA, Rubink WL, Pinto MA, Coulson RN (2005) Spatial and temporal distribution and nest site characteristics of feral honey bee (Hymenoptera: Apidae) colonies in a coastal prairie landscape. Environ Entomol 34:610-618

Baum KA, Tchakerian MD, Thoenes SC, Coulson RN (2008) Africanized honey bees in urban environments: a spatio-temporal analysis. Landsc Urban Plan 85:123-132

Bieńkowska M (2012) Use of honey bee queens by beekeepers in Poland [in Polish, original title: Gospodarka matkami pszczelimi w Polsce]. In: Naukowa Konferencja Pszczelarska, pp. 18-19. Puławy

Brown MJF, Paxton RJ (2009) The conservation of bees: a global perspective. Apidologie 40:410-416

Corbet SA, Unwin DM, Prys-Jones OE (1979) Humidity, nectar and insect visits to flowers, with special reference to Crataegus, Tilia and Echium. Ecol Entomol 4:9-22

Couch SM (1992) The practice of avenue planting in the seventeenth and eighteenth centuries. Gard Hist 20:173-200

Crane BG (2001) An evaluation of the management options available for the regeneration of neglected avenues. Arboricult J 25:23-25

De la Rua P, Serrano J, Galian J (1998) Mitochondrial DNA variability in the Canary Islands honeybee (Apis mellifera L.). Mol Ecol 7:1543-1547

De la Rúa P, Jaffé R, Dall'Olio R, Muñoz I, Serrano J (2009) Biodiversity, conservation and current threats to European honeybees. Apidologie 40:263-284

Dietemann V, Pirk CWW, Crewe R (2009) Is there a need for conservation of honeybees in Africa? Apidologie 40:285-295

Galton D (1971) Survey of a thousand years of beekeeping in Russia. Bee Research Association, London

Haragsim O (1977) The nectar secretion of maple (Acer platanoides L.) and sycamore (A. pseudoplatanus L.). Apidologie 8:363-368

Jaffé R, Dietemann V, Allsopp MH, Costa C, Crewe RM, Dall'Olio R, de la Rúa P, El-Niweiri MAA, Fries I, Kezic N, Meusel MS, Paxton RJ, Shaibi T, Stolle E, Moritz RFA (2010) Estimating the density of honeybee colonies across their natural range to fill the gap in pollinator decline censuses. Conserv Biol 24:583-593

Jensen AB, Palmer KA, Chaline N, Raine NE, Tofilski A, Martin SJ, Pedersen BV, Boomsma JJ, Ratnieks FLW (2005) Quantifying honey bee mating range and isolation in semi-isolated valleys by DNA microsatellite paternity analysis. Conserv Genet 6:527-537

Kondracki J (2002) Geografia regionalna Polski [Regional geography of Poland]. Wydawnictwo Naukowe PWN, Warszawa

Larsen FK, Kristoffersen P (2002) Tilia's physical dimensions over time. J Arboric 28:209-214

Lehmann I, Rohde M (2006) Alleen in Deutschland: Bedeutung, Pflege, Entwicklung, Edition Leipzig, Leipzig

Lowe EC, Simmons LW, Baer B (2011) Worker heterozygosity and immune response in feral and managed honeybees (Apis mellifera). Aust J Zool 59:73-78 
Magnus RM, Tripodi AD, Szalanski AL (2011) Mitochondrial DNA diversity of honey bees, Apis mellifera L. (Hymenoptera: Apidae) from queen breeders in the United States. J Apic Sci 55:37-46

Maul V, Hähnle A (1994) Morphometric studies with pure bred stock of Apis mellifera carnica Pollmann from Hessen. Apidologie 25:119-132

McNally LC, Schneider SS (1996) Spatial distribution and nesting biology of colonies of the African honey bee Apis mellifera scutellata (Hymenoptera: Apidae) in Botswana, Africa. Environ Entomol 25:643-652

Meixner M, Worobik M, Wilde J, Fuchs S, Koeniger N (2007) Apis mellifera mellifera in eastern Europe-morphometric variation and determination of its range limits. Apidologie 38:191-197

Moritz RFA (1991) The limitations of biometric control on pure race breeding in Apis mellifera. J Apic Res 30:54-59

Moritz RFA, Kraus FB, Kryger P, Crewe RM (2007) The size of wild honeybee populations (Apis mellifera) and its implications for the conservation of honeybees. J Ins Conserv 11:391-397

Morse RA, Camazine S, Ferracane M, Minacci P, Nowogrodzki R, Ratnieks FLW, Spielholz J, Underwood BA (1990) The population density of feral colonies of honey bees (Hymenoptera: Apidae) in a city in upstate New York. J Econ Entomol 83:81-83

Oldroyd BP, Lawler SH, Crozier RH (1994) Do feral honey bees (Apis mellifera) and regent parrots (Polytelis anthopeplus) compete for nest sites? Aust J Ecol 19:444-450

Oldroyd BP, Thexton EG, Lawler SH, Crozier RH (1997) Population demography of Australian feral bees (Apis mellifera). Oecologia 111:381-387

Oleksa A, Ulrich W, Gawroński R (2006) Occurrence of the marbled rose-chafer (Protaetia lugubris Herbst, Coleoptera, Cetoniidae) in rural avenues in northern Poland. J Ins Conserv 10:241-247

Oleksa A, Ulrich W, Gawroński R (2007) Host tree preferences of hermit beetles (Osmoderma eremita Scop, Coleoptera: Scarabaeidae) in a network of rural avenues in Poland. Pol J Ecol 55:315-323

Oleksa A, Chybicki I, Tofilski A, Burczyk J (2011) Nuclear and mitochondrial patterns of introgression into native dark bees (Apis mellifera mellifera) in Poland. J Apic Res 50:116-129

Pacyniak C (1992) Najstarsze drzewa w Polsce [The oldest trees in Poland]. Wydawnictwo PTTK "Kraj”, Warszawa

Pradines C (2009) Road infrastructures: tree avenues in the landscape. Council of Europe, Strasbourg

Rangel TF, Diniz-Filho JAF, Bini LM (2010) SAM: a comprehensive application for Spatial Analysis in Macroecology. Ecography $33: 46-50$
Ratnieks FLW, Piery MA, Cuadriello I (1991) The natural nest and nest density of the africanized honey bee (Hymenoptera: Apidea) near Tapachula, Chiapas, Mexico. Can Entomol 123:353-359

Rowntree RA, Nowak DJ (1991) Quantifying the role of urban forests in removing atmospheric carbon dioxide. J Arboric 17:269-275

Ruttner F (1988) Biogeography and taxonomy of honey bees. Springer, Berlin

Schneider S, Blyther R (1988) The habitat and nesting biology of the African honey bee Apis mellifera scutellata in the Okavango River Delta, Botswana, Africa. Insectes Soc 35:167-181

Schneider SS, DeGrandi-Hoffman G, Smith DR (2004) The African honey bee: factors contributing to a successful biological invasion. Annu Rev Entomol 49:351-376

Seeley TD (1978) Life history strategy of the honey bee Apis mellifera. Oecologia 32:109-118

Seeley TD, Morse RA (1976) The Nest of the Honey Bee (Apis mellifera L). Insectes Soc 23:495-512

Semkiw P, Skubida P (2010) Evaluation of the economical aspects of Polish beekeeping. J Apic Sci 54:5-15

StatSoft, Inc. (2011). STATISTICA (data analysis software system), version 10. www.statsoft.com

Tartaro P, Kunz S (2008) Bestand und Bedeutung von Alleen und Alleenlandschaften in der Schweiz. Stiftung Landschaftsschutz Schweiz, Bern

Quantum GIS Development Team (2010) Quantum GIS geographic information system open source geospatial foundation project http://qgis.osgeo.org

Thompson C, Budge G, Biesmeijer J (2010) Feral bees in the UK: the real story. Bee Craft 92(4):22-24

Ulrich W (2003) Sample-a FORTRAN program for taking series of random samples www.uni.torunpl/ulrichw

Ulrich W, Ollik M (2005) Limits to the estimation of species richness: the use of relative abundance distributions. Divers Distrib 11:265-372

Visscher PK, Seeley TD (1982) Foraging strategy of honeybee colonies in a temperate deciduous forest. Ecology 63:1790-1801

Waś E, Rybak-Chmielewska H, Szczęsna T, Kachaniuk K, Teper D (2011) Characteristics of Polish unifloral honeys. II. Lime honey (Tilia spp.). J Apic Sci 55:121-128

Wenner AM (1989) "Bee-lining" and ecological research on Santa Cruz Island. Am Bee J 129:809-810

Woś A (1999) Klimat Polski [The climate of Poland]. Wydawnictwo Naukowe PWN, Warszawa 